\title{
Cultivating Public Readers: Citizens, Classes, and Types
}

\begin{abstract}
This chapter considers readers in the southern colonies, from various constructions of reader types to the class, gender, and racial composition of colonial reading publics. Locating the users of colonial public libraries within discourses that include sexuality, morality, citizenship, race, and class, the chapter looks at the ways in which public libraries contributed both to expanded understandings of the term 'public' and to the management of colonial class and race relations, thereby reflecting and redefining the boundaries of citizenship in emerging colonial polities.
\end{abstract}

Keywords Reading publics $\bullet$ Working-class readers $\bullet$ Loafers $\bullet$ Women readers $\bullet$ Indigenous readers

Patrick Joyce has argued that the rise of free municipal libraries in Britain in the mid- to late-nineteenth century was essential to the emergence of a 'new vocabulary of the social', particularly as it related to revised and expanded understandings of the term 'public'. The idea of a free institution funded by the public purse meant that the individual subject was not so much attached to different voluntary organisations or to the market or even to the state, but rather to a new sense of ordinary communal citizenship grounded in liberal and, increasingly, democratic values. In contrast to the earlier efforts of subscription libraries to consolidate middle-class

(C) The Author(s) 2019

L. Atkin et al., Early Public Libraries and Colonial Citizenship

in the British Southern Hemisphere, New Directions in Book History, https://doi.org/10.1007/978-3-030-20426-6_3 
and elite values, the British public library movement was to give the working classes free access to the public realm, thereby 'constituting it as demotic'. ${ }^{1}$ A similar trajectory towards new forms of liberal, democratic citizenship can be traced via the library history of the southern colonies, but the self-improvement culture of the British public library movement nonetheless had to be adapted and modified in the colonial context. Accounting for, among other things, the education of Indigenous, mixedrace, and multi-ethnic populations, different forms and conditions of white and Indigenous labour, and the accelerated developmental pace of colonial societies would require locally specific understandings and conceptions of the term 'public' as the nineteenth century progressed. It would also require public libraries to address and account for particular kinds and classes of readers from diggers, bushmen, and Indigenous populations to squatters, tradesmen, and urban elites.

If, as Michael Warner has argued, a public exists only by virtue of being 'addressed in discourse' or, in other words, as 'a space of (discursive) circulation', the ways in which public libraries cultivated and/or excluded certain types of readers were essential to developing colonial identity formations. ${ }^{2}$ David Wittenberg has rightly noted that ' $[\mathrm{t}] \mathrm{o}$ be part of a public, to be part of the public, is to be at once both an actor and a stand-in'. ${ }^{3}$ Public libraries were not, therefore, only social spaces where actual readers could physically congregate, but also discursive spaces in which local presses and library management committees could cultivate ideal reading types that reflected the social values to which emerging colonial polities aspired. In so far as available source material permits, this chapter addresses colonial reading publics in both a notional and an empirical sense, looking at the ways in which reading communities in the colonies reflected the practices of actual readers and the construction of reader archetypes. Reader types, like character types, can be defined as what Ken Gelder, Rachael Weaver, and Elizabeth Fowler have called 'models of social identity' or 'social persons' that act as analogues of real persons. ${ }^{4}$ Depictions of colonial readers of every class and type, from diletantish 'loungers', unemployed 'loafers', and 'careless skimmers of the last romance' to scholars, blue-stockings, and 'curious annotators in the library of reference', therefore represent a kind of constructed sociology of colonial life, one thatperhaps even more than actual readerships-was used to define and police the boundaries of citizenship in the southern colonies. ${ }^{5}$ 


\section{Working and Middle-Class Readers}

In a revealing letter to the Sydney Morning Herald in 1869, an anonymous 'Reader' argued that a truly public library would be freely circulating so as to cater for the needs of the 'mass of the population', who 'have to read by snatches of time; many at hours when a public library could not be open'. ${ }^{6}$ Concluding that the establishment of a reference library in Sydney would result in the persistence of the kind of closed 'coterie $[s]$ of professed littérateurs' that haunted both the BML and the MPL, ' the correspondent noted that ' $[\mathrm{t}]$ he people who can go into a public library in the day time are not the public' but rather the leisure classes and other elites. The correspondent's association of the 'public' with the working 'masses' rather than with the gentlemanly leisure classes points, most obviously, to new understandings of the public as the ordinary working people, but it is also suggestive of the relationship between expanded definitions of the term and democratic suffrage. A 'mere public library without a loan arrangement', argued the correspondent, would be of 'little use to the masses, in whose hands we have placed the franchise, and in whose hands we should place first-class books'. ${ }^{8}$

While it is hard to be sure of the class and gender locations of anonymous correspondents to newspapers, who often used pseudonyms and engaged in complex acts of subject positioning, the primarily middle-class readership of newspapers such as the Sydney Morning Herald is suggestive of the extent to which the colonial middle classes saw their own societies as (potentially) more egalitarian than those of the metropoles. This sense of democratic potential even permeated the book acquisition policies of library management committees. In 1879, the SAI particularly regretted that its reference collection was deficient in works of 'constitutional history, polity and their allied subjects' because South Australia was 'a democratic community and enjoying universal suffrage'. ' In arguing for increased book provision for the working classes, the anonymous correspondent also assumes the high literacy competencies of colonial working-class populations: all they require, he argues, is free access to 'first-class books'. Studies of literacy in emigration populations in mid-nineteenth-century Australia do indeed point to higher educational attainments among emigrants from Britain and Ireland in comparison to their respective regional home populations. This is true both of convicts and free settlers, and was particularly pronounced in the colonies of New South Wales and Victoria. ${ }^{10}$ In 1862 , Victoria's literacy rate was 'twice that of Britain's, far higher than London's or any other colony's, and one of 
the highest in the world'. ${ }^{11}$ Kathleen Fennessy estimates that by $188195 \%$ of people of both sexes in Victoria could read and $88 \%$ could write. ${ }^{12}$ According to the 1865 census in the Cape Colony, 65.7\% of whites in the Western Cape were literate and $63.9 \%$ in the Eastern Cape, whereas only 9.7\% of the black and African populations could read. ${ }^{13}$ In Singapore, nineteenth-century literacy rates among the small, largely middle-class white populations were high but, even by 1921, literacy rates among the whole population (primarily Malays and Chinese) were only $36.6 \%$ for all languages and $8.3 \%$ for English. ${ }^{14}$

Despite the relatively high literacy rates among European settlers, it is difficult to know from the available sources how many working-class readers frequented public libraries in the southern colonies or what they read. Ann L. Stoler has rightly argued that the 'presence of poor whites in the colonies was far more widespread than most colonial histories lead us to imagine', ${ }^{15}$ but the white working-class population was negligible in the southern hemisphere in all but the Australian and New Zealand colonies. Franchise colonies such as the Cape Colony, where Indigenous and local populations far outweighed settler populations, tended to use local, immigrant, or indentured labour rather than white working-class labour. In the Cape, a shortage of skilled working-class labourers was a constant complaint, and debates about the introduction of a lower third rate of subscription at the SAPL in 1848 were framed around the need to make the library accessible to lower-middle-class professionals rather than the working classes. ${ }^{16}$ The SAPL was therefore nearly exclusively the domain of middle-class white men, including a relatively large number of 'gentlemen from India' (generally civil servants on leave from Bengal) and 'military in garrison' who were considered prestigious additions to the library's membership, and swelled otherwise fairly small and static subscription numbers. ${ }^{17}$ The small artisanal working-class population in Cape Town was primarily served by Alexander Jardine's Popular Library. ${ }^{18}$ In Singapore, the white working class was even smaller than in the Cape, and the SL and RLM were also predominantly used by the white middle classes. The introduction of a cheaper library subscription rate in 1847 saw an increase in the number of female subscribers and lower-middle-class administrators but did not substantially change the demographic of the SL's users. ${ }^{19}$

The Australian colonies, on the other hand, had relatively high numbers of both skilled and unskilled labourers, many of whom were encouraged by the gold-rush emigration of the $1850 \mathrm{~s} .{ }^{20}$ In colonial Tasmania, for example, the 1870 census, published the year the TPL opened, provides a 
four-tiered structure of professional/commercial class (5\%), middle-class waged $(20 \%)$, industrial class $(34 \%)$, and labouring class $(41 \%) .{ }^{21}$ The subscription and circulation figures of public libraries in colonial Australia unfortunately provide little indication of the class or gender proportions of library users, and references to working-class readers are largely anecdotal. The Melbourne Herald claimed that the MPL's Queen's Reading Room was 'crowded with persons of all classes', but provides no sense of the number of readers from each class. ${ }^{22}$ The Age stated that most of the MPL's readers were 'bona fide workers', while the Australasian claimed that the library was 'largely used by the better class of artisans' and that 'many men studied the science of their occupation'. It appears from press comments such as these that the bulk of the MPL's users were the 'lower middle classes, clerks, professional men and skilled artisans' rather than the working classes or the upper middle classes, the latter of whom were wealthy enough to have their own private libraries. ${ }^{23}$

The Sydney FPL's early users, on the other hand, appear to have been primarily working class, with the library's trustees noting in their report for 1877 that 'an erroneous impression had formerly prevailed that the institution was simply a reading-room and a library for the working classes' rather than 'a Public State Library for all classes'. If by 1878 the FPL was being 'extensively used by students of all classes', including those 'persons of superior culture, who formerly kept away', the library does seem to have been used by readers who would normally have been members of mechanics' institutes. ${ }^{24}$ In 1856, the SAI noted that 'we are ... assuredin fact, numerous autographs in the "Application Book" prove the statement- that our rural settlers and bushmen are taking great interest in the establishment', suggesting that the non-urban working class was at least visiting the library during trips to the city. At the other extreme, an article on mechanics' institutes in the Mount Alexander Mail (Castlemaine, Victoria) claimed that 'a prejudice exists in the Melbourne Public Library, against anything hailing from the diggings, and the feeling was some time ago offensively manifested by the ejection from the reading room of two miners who had the audacity to appear in their woollen jumpers in that repository of wisdom'. ${ }^{25}$

Notwithstanding the commitment of public libraries to universal adult education, the alleged ejection of inappropriately dressed diggers from the MPL is suggestive of the extent to which such libraries were markers of middle-class respectability. Establishing hierarchies of readers from the 'imperious Fitzjones, of the Civil service' to 'Smith, his carpenter', the 
conservative Melbourne Herald suggested in 1875, for example, that while the 'perfect freedom of entrance' associated with the MPL was in theory pleasing to a 'democratic community', it had its limits. 'Much could be forgiven', the Herald argued, 'if the Library were rendered a little more pleasant for the decent and cleanly classes'. ${ }^{26}$ Decent workingclass men and women or the 'honest labouring poor' were therefore differentiated from the under-class of loafers, vagabonds, and other types of 'undeserving' poor discussed later in this chapter, but they were not immune from scrutiny, particularly in relation to complaints about the overcrowding of the library. In a parody of negative representations of working-class readers in conservative papers, Melbourne Punch depicts a bunch of 'tailors of a studious turn' who are seated on the floor like 'Turks' and to whom 'the paucity of chairs is of little importance', resulting in the paper's ongoing tongue-in-cheek concern with the vulgarity of public facilities: "Public" stands, in short, for vulgar-for instance take a few / Public cases— "publichouses", "public men" and-“women", too!'. ${ }^{27}$

Punch plays here on fears that public libraries and other public spaces might become places of ill-repute, encouraging the kind of vulgar behaviour associated with inebriated men and loose women. Public libraries certainly drew on the rhetoric of respectability, family life, and domestic economy in order to regulate the use of their spaces, encouraging personal habits such as good hygiene and ventilation, habits of temperance, economy and time management, and disciplined reading practices in their users in an attempt to incorporate such users into the 'larger social structures' of family, work, and community. Conferring both social stigma and an opportunity to overcome it, public libraries were therefore alert to the 'pedagogic functions of reading' and their potential effect on a broad range of social behaviours. ${ }^{28}$

Mary Hammond has noted, in the British context, the extent to which the reader was constructed through class-inflected routines as well as 'through the social functions linked to the public spaces in which books were selected, displayed, and read'. ${ }^{29}$ While the Herald imagined Fitzjones (the civil servant) and Smith (his carpenter) reading side-by-side, the very ceremony of signing one's name or requesting books from librarians could be off-putting to working-class and lower-middle-class readers, as could the size and scale of public buildings, the new competencies required to navigate modern catalogues and access policies, and the rarefied practices of silent and solitary reading. There is evidence to suggest that Redmond Barry intended the portico entrance of the MPL's classical building, added 
in 1870 , to be a mediatory architectural device linking street and interior, people and books, ${ }^{30}$ but in an article in 1867, Melbourne Punch portrays the 'great Antipodean Lyceum' as a 'sacred fence' or gateway to knowledge that is eminently unwelcoming to the unsuspecting 'stranger'. First being forced to meet 'the lazy and passive stare of the policeman at the door' who is there to prevent the theft of books, the would-be reader is then required to write his name in a book. Rejecting that as 'an unwarranted intrusion of the liberty of the subject', Punch's reader walks along the 'silent cocoanut matting' to the washbasin to wash his hands surrounded by 'casts of certain ancient chef d'oivres' and 'prints of Raphael's cartoons'. The increasingly dirty towel mounted on a roller by the doublebarrelled hand-wash apparatus provides, Punch jokes, a 'goodly lesson' and 'is doubtless provided by the trustees for the purposes of showing what may be effected by indomitable energy and praiseworthy perseverance'. Finally, at the door to the reading room, the visitor is given 'a neat little lecture on social ethics-he is told - to take off his hat!'. ${ }^{31}$

These kinds of rules and rituals surrounding the use of library spaces are not only suggestive of middle-class pressures on the working classes to dress and act a certain way, but also served to turn the library-going public into a kind of 'public police'. As Redmond Barry acknowledged in his address at the opening of the Ballarat Free Public Library in 1869, the point of library regulations relating to dress, cleanliness, and behaviour was to encourage 'social conformity', although he was emphatically against the seemingly 'insatiable desire' for 'superintending the studies' of readers. ${ }^{32}$ The 'social psychology' of the nineteenth-century library as a disciplinary space was also evident in the ways in which library spaces were organised, from the display of busts of prominent liberal thinkers and ornamental books to the open, radial 'palatial design' of reading rooms, which enabled both 'the chance to view the giant structure of knowledge as a whole' and the panoramic viewing of the many by the many. ${ }^{33}$ A more explicit form of surveillance came both from the policemen stationed at the front of libraries such as the MPL and the SAI to prevent the theft of books, and from library staff. 'A Visitor to the Public Library' in 1863 proposed for the MPL a system already in place in 'the large free libraries of Liverpool and Manchester', namely, a slip recording a borrower's address and the number of the book borrowed. Such a system, the correspondent argued, would ensure that 'a check is placed on each reader that enters the room'. ${ }^{34}$ A similar method of recording borrowings in a designated book was introduced at the SL from the outset, along with an inspection of returned books by the librarian. ${ }^{35}$ 
These kinds of 'bureauropathetic behavior[s]' or 'checks', along with other forms of surveillance, were a large part of a librarian's role in the nineteenth century. ${ }^{36}$ As the South Australian Weekly Chronicle noted in a debate on the merits of free access to library shelves, the books at the SAI 'are directly under the charge of the Librarian, Mr. P. S. Benham, and no person is allowed access to them on the shelves except for purposes of reference or study'. ${ }^{37}$ Such service-oriented procedures allowed librarians to supervise, track, and monitor users, as well as to record their activities in registers and logbooks. Even readers at the open access MPL remained under the 'direct physical observation' of library staff. ${ }^{38}$ In a parody of the overinflated selfimportance of the MPL reader in 1864, Melbourne Punch noted that ' $\mathrm{Mr}$ A. Wake's' daily visits were often disturbed by the sub-librarian, who, 'regardless of the profundity of his cogitations, says - "You must not sleep here!". 39

The censoring of books was an additional form of middle-class surveillance and control. Comparing the governing committee of the SAI to a 'conclave' of 'high-priests of literature', the South Australian Weekly Chronicle argued that no group of people should 'decide dogmatically what the colony may read and what the colony may not', and that censorship in a 'national library' was 'opposed to the tendencies of modern thought'. ${ }^{40}$ The Chronicle's view that a national library should include even dangerous reading material was echoed in Singapore, where Brendan Luyt has shown that the RLM contained fiction which had been censored in many American and British libraries. ${ }^{41}$ Most public libraries in the colonies were, however, concerned with the moral character of their collections, and attempted to provide their readers with improving material and only the best kind of 'standard' fiction (see Chap. 4). In many ways, this was the result of their middle-class governance structures. While the liberal principles of public libraries supported free access as far as respectability and social decorum would allow, their governance was almost invariably in the hands of coteries of propertied men of public, professional, or commercial distinction, giving these men a very significant role as colonial censors and knowledge brokers. The boards of trustees of public libraries therefore operated almost as an extension of the predilection for a genteel club life dominated by ethnic, ideological, or religious kinship, which was one of Britain's most distinctive cultural exports to its colonies. ${ }^{42}$ Before the professionalisation of library studies, chief librarians, too, tended to be middleclass males like Augustus Tulk and Alexander Jardine, suggesting the gendered and class-inflected recruitment patterns of equally maledominated library governance committees. 
The potentially levelling function of the public library as an open, meritocratic institution must therefore be set against the fact that such libraries were generally run by, and catered for, a select middle-class public, who engaged in various forms of paternalism, censorship, and surveillance, and whose interests were often removed from working-class auto-didactic cultures and from the needs of the general public in its new expanded sense. ${ }^{43}$ As in Britain, the colonial public library became, more often than not, what Hammond has called an 'architecturally repressive and logistically prohibitive symbol of civic pride patronized overwhelmingly by the lower middle classes'. It was a space, in other words, 'that ended up militating against large sections of the population whom it had been intended to serve'. ${ }^{44}$

\section{LOUNGERS, LOAFERS, AND IDLERS}

Some of the greatest nuisances faced by the colonial public library, according to the local press, were the characters of the lounger and loafer. Depictions of loungers and loafers ranged from providing a source of entertainment and mockery, to being seen as a public irritant, and finally, to being viewed as a danger to public order and respectability. Melbourne Punch, for example, got significant mileage out of the loafer character as a means of mocking the content of the MPL's collections as well as its lofty designs as a national institution for public education. In a squib titled 'Sleeping Arrangements', Punch announced that the MPL was now accepting 'loafers and others' in its 'commodious and well ventilated building' for a 'comfortable doze any time from ten a.m. to ten p.m.', adding that '[b]ooks calculated to induce somnolency can be had on application' ${ }^{45}$ Most letters and editorials concerning the lounging and loafing class were not, however, as amused by their presence in the library, with the Melbourne Argus writing that "[y] ou will inevitably be distracted if you have sitting close by you an unpleasant-looking street lounger, perhaps with suspicious restlessness turning over books you want to consult, perhaps breathing heavily in sleep, but in either case redolent of uncleanliness and gin'. ${ }^{46}$ Increasingly, the library became a battleground for middleclass sensibilities and, although lounger and loafer were initially terms used interchangeably, the lounger became a more benign 'idler' while the loafer came to assume a more insidious figure associated with the unemployed and criminal lower classes. ${ }^{47}$

Coupled with 'light reading' (see Chap. 4), if any reading at all, the presence of loungers and loafers in the public library was a much-debated topic, 
even if, in reality, the number of loafers was probably small and confined to a few repeat offenders. In a letter to the Philosophical Society of Queensland, Redmond Barry noted that book purchases for the MPL were specifically designed to dissuade these characters by 'admitting no works of a trivial or ephemeral character, which, serve merely to dissipate the idle hours of the lounger'. ${ }^{48}$ In 1856, the Melbourne Age similarly pointed to the scholarly, and somewhat dour, nature of the MPL's original collection as a safeguard against both loungers and improper, frivolous reading practices, insisting that 'on no account ... must the Library be made a mere lounging room for casual readers of magazines and newspapers, or a circulating library for the lovers of cheap fictions'. While nominally supporting the principles of free public access, it supposed that maintaining an ambitious, universalist focus would in itself ensure that patronage would be appropriately limited to the 'few' colonial cognoscenti or 'zealous devotees of literature who haunt its quiet and grateful precincts' ${ }^{49}$ By 1860, the Age noted that its prescription had not come to pass, and complained that the institution had instead become 'the paradise of loafers and loungers, who completely subvert the actual uses and intents of the place'. ${ }^{50}$

Although the male loafer-women were accused of many crimes in the library, but loafing was not one of them-found his way into libraries in other southern colonies, as well as in North America and Britain, the MPL was viewed as particularly vulnerable to loafers because its shelves were open access, it had generous opening hours, and it was open to anyone over the age of 14 . As David McVilly notes in his history of the MPL, during the 1860s and 1870s 'hardly a month passed without an editorial writer or letter-writer complaining of loafers and loungers who used the Library for amusement purposes rather than for the serious purposes for which it was intended'. ${ }^{51} \mathrm{McV}$ illy rightly argues that the representation in the local newspapers of these undesired library users most often came from the pen of the middle classes, and that 'admirers of the Library seem to have overreacted to its possible misuse' and fully subscribed to the 'utilitarian and puritanical principles on which it was based'. ${ }^{52}$

To the most militant of observers, these characters threatened to undermine not only the utility, respectability, and perceived purpose of the public library, but also the very productivity of the colony itself. The Argus wondered if the MPL was too much of a 'temptation', and if access to the library was made more select then the 'array of loafers' might find 'some occupation more beneficial to society and to themselves'. In contrast to the argument in favour of public libraries as providing opportunities for 
self-improvement and rational recreation for the working classes, the Argus proposed a cost-benefit analysis of the public good offered by the MPL, asking whether the "little knowledge", proverbially dangerous, which they acquire ... can in any way compensate a community such as ours for the loss of so many vigorous arms, and what might otherwise be so many honest toil-stained hands? ${ }^{53}$ During his address at the opening of a mechanics' institute in New South Wales, the pastoralist Gideon Lang also raised the question of utility, identifying three classes of workers with the third class being 'the loafers, a set of lazy ruffians, of every grade, count, and occupation, who came out originally to the diggings because unfit for any steady, industrious pursuit at home, and for the same reason had taken advantage of the system of "loafing" prevailing in the pastoral districts to become vagabonds'. ${ }^{54}$

The loafer figure could appear in numerous guises-from Lang's pastoral figure to the metropolitan 'ruffian'-but, as Michael Zakim has argued in the North American context, its 'omnipresence' in the public mind 'was testimony to an emerging labor problem: a crisis in the meaning of industriousness that had been provoked, aptly enough, by an industrial revolution' ${ }^{55}$ As in North America, the 'problem of the loafer' was increasingly viewed in the southern colonies as a class issue driven by unemployed, indolent labour. Although unemployment would not become acute in the Australian colonies until the severe depression of the 1890s, the boombust cycles of the gold rush had, according to Marx, led to the early 'glut of the Australian labour market' and the peripatetic men the gold diggings attracted were viewed with increasing anxiety. ${ }^{56}$ Criticisms levelled by the Age against the MPL for allowing access to these loafers was not solely because the library was wasted on them, but also because they discouraged more respectable readers from using the library by occupying tables and chairs. The unwanted and unwashed loafer is often contrasted with the 'studious', industrious, and respectable student who is in the library to pursue 'systematic study' or to make 'references and extracts for literary uses'. ${ }^{57}$ The loafer was thus seen to pose a threat to serious intellectual endeavours and the progress of the colony. The Argus urged that a separate room with 'greater facilities for note-making' be created for the 'better kind of students, supplied with writing materials, served by one or two attendants, and open only to those who can give evidence of a serious intention'. ${ }^{58}$

Loafers were accused of further impeding serious study by damaging and stealing the library's books. Frequent appeals were made to the 
benefits of the reading card application system of the BML, which, if adopted in Melbourne, would be a 'means of excluding a class whose room is better than their company, while it would offer no real impediment to the well-intentioned reader' ${ }^{59}$ Although most newspaper reports associated the damage and theft of books with loafers or the working classes, some like an article in the Herald came to their defence, arguing instead that the loafer's 'malodorousness, his unclean fingers, his general qualities of unwashedness are only lightly objectionable, compared with the determined vandalism of the respectable and educated frequenter of that most admirable institution' ${ }^{60}$ Melbourne Punch lampooned the tendency to blame the 'carbonaceous deposit' accumulated on the skin of the 'sons of toil' for the soiling of books by drawing 'a connection between mechanical knowledge and mechanical dirt'. Punning on the self-help culture of the public library movement, Punch jokes that 'it is these selfhelping gentlemen who soil the books'. ${ }^{61}$

Complaints about the damage of books by unwashed hands of all classes were certainly frequent, with a report in the South Australian Weekly Chronicle criticising the state of books at the SALMI, where 'should a person desire to look up a passage in the works of any leading author ... it will probably be in a filthy state of grease and dirt, reeking of tobacco smoke or stale beer, and possibly containing marginal notes made by aspiring youths with greasy fingers'. ${ }^{62}$ The damage done to books by smoking was also remarked upon in the 1850 SAPL report and in the Cape of Good Hope Literary Gazette, which pointed to 'that numerous race of careless unthinking' despoilers, from 'bed-readers' and 'segar smokers' to 'coffee drinkers' and 'general loungers', noting that 'not the least of the aggressors' are 'those who scribble with the pen or pencil, and record the marginal nonsense of their own composing'. ${ }^{63}$ The frequent lamentations about the abuse of books by colonial newspapers and libraries alike can occasionally give us glimpses into what was being read, with the Herald reporting that the 'volumes of the dramatists are dirtied and mutilated to a disgraceful extent', and that the 'favourite authors of the "loafing" fraternity' were 'the more licentious specimens of the literature of the Elizabethan and succeeding periods'. Volumes of Walter Scott and Dryden are both recorded as being 'mutilated', while 'Massinger Ford, and a few others, are thumbed and torn, and so of course, is "Don Juan"". ${ }^{64}$

The middle-class obsession with overcrowding and cleanliness, and in particular with the requirement that readers wash their hands before entering the MPL, was the target of a number of Melbourne Punch articles, 
some of which pointed out that hand-washing encouraged the very loafers that the library was seeking to discourage. A Punch illustration from 1887, for example, shows the MPL's chief librarian from 1881 to 1895, Thomas Francis Bride, angling for 'soap stealers' and catching three 'very queer fish', all of whom are clearly undesirable loafers (Fig. 3.1). ${ }^{65}$ While the

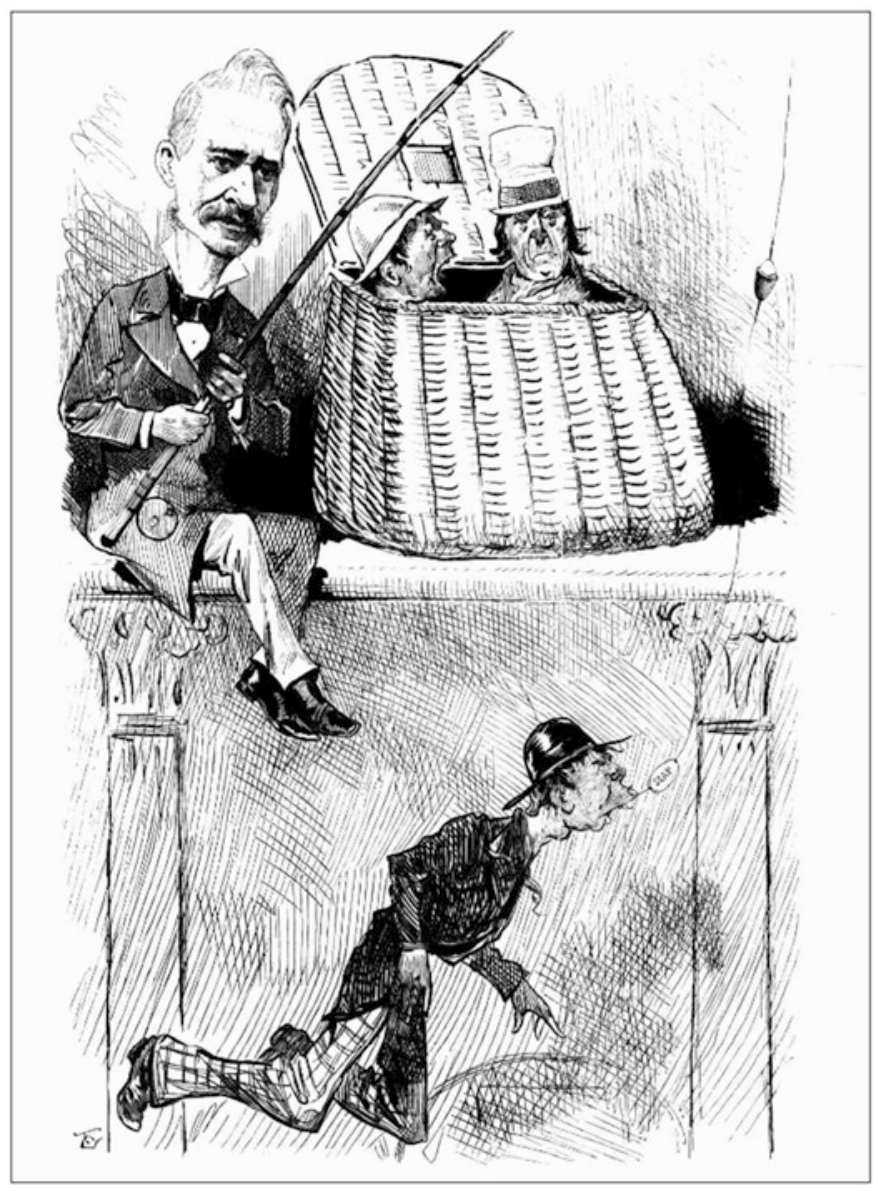

Fig. 3.1 'While There's Life There's Soap', wood engraving, Melbourne Punch, January 13, 1887, 15. Courtesy of Trove: https://trove.nla.gov.au/newspaper/ page $/ 20442557$ 
constant references in the press to unwashed loafers and the repeated complaints about soap being stolen from the library reveal the class tensions unfolding within the walls of the public library, uncleanliness did pose a significant problem - and not only to the books. Calling the loafer a 'practical entomologist', the Herald points to the fear of insect- and pest-carrying individuals but also to the concern that books could spread diseases ${ }^{66}$ Alexander Black has noted in the British context the extent to which the massification of the library and its wider role as a 'clinic' for social diseases led to exaggerated fears about the spread of physical diseases via both germs from dirty hands and atmospheric impurities or poor ventilation in shared spaces. ${ }^{67}$

Pathologising dirtiness was, of course, a form of social control designed to keep out those deemed undesirable. As Harald Fischer-Tiné has argued, loafers posed a 'latent threat to [European] civilising ambitions' and could lower 'European prestige' by blurring the hierarchies between coloniser and colonised. Efforts to police the 'transgressive' loafers in the MPL therefore became part of an 'internal civilising mission'. Encouraging clean hands was ostensibly meant to preserve books, but it was also a way of discouraging vagabonds and those in manual labour or the 'dirty professions', as well as consolidating the public library space as one primarily for the 'decent', cleanly lower middle classes who 'conform[ed] to civilised habits' ${ }^{68}$

\section{WOMEN READERS}

A parody letter written to the Sydney Morning Herald in 1844 indicates the figurative power of the woman novel reader who frequents the library. Signed 'Lavinia Readmuch', the writer identifies herself as a 'subscriber to the Australian Subscription Library' and describes her discriminate reading habits as 'being rather choice ... I do not on an average read above six novels a week, with the occasional dip into a new poem-when there is such a thing'. The complaint 'Readmuch' levels against the ASL is that smokers are ruining her reading experience: 'some of the nasty creatures read novels when they are smoking-and the consequence is, that ... the whole book becomes impregnated with tobacco, until it smells as bad as a tobacconist's shop'. Whether the letter-writer is using the figure of the woman reader to criticise the practice of smoking - as noted above, a common concern of library management committees-or simply mocking the criticism itself, it nonetheless demonstrates the potency of the woman reader encroaching on male space. Her reading habits are frivolous: the 
reading of six novels a week does not indicate a serious or considered reading practice and sexual innuendos litter the text. On appealing to the ASL committee to end the nasty habit of smoking, 'Readmuch' writes: 'do your best to put an end to it, there's good souls; and if you succeed, I'll (but I musn't say what I'll do, for it will look like bribery)'. ${ }^{69}$

The licentious, ravenous novel reader was not the only type of female reader satirised for attending the colonial public library. As early as 1841, the SAPL recognised another female presence: that of the colonial bluestocking. Stressing the need for the SAPL to appeal both to the serious student and the general reader, 'uniting the instruction with the recreation of the mind', Advocate Musgrove argued that 'we are not all equally gifted, or destined to explore the paths of literature and science. It is not everyone who reads merely for the sake of being edified, nor is it every lady who wishes to become a Blue Stocking' ${ }^{70}$ An 1868 Melbourne Punch article describing the 'women of the time' in Melbourne draws a mocking portrait of the colonial blue-stocking: 'an awfully well-read young lady' who had 'been a governess; but owing to paternal speculations in gold mines having curiously enough turned out successfully, she has relinquished the drudgery of teaching'. The blue-stocking is much too serious for novel reading, with the Punch writer 'feeling abashed' that he 'was carrying home Miss BRADDON's last novel' while she was reading 'Ecce Homo and Darwin's Species'. Spending 'most of her time in the Public Library', the blue-stocking occupies a different, but equally troubling, position in the male-dominated space of the library as the female novel reader. As we can see from the parody in Fig. 3.2, women occupy all the seats in the science section-'she knows ever so much of botany, conchology, paleontology' - and they thus both distract and prevent the learned gentleman from taking his seat and pursuing the scientific studies necessary for the benefit of the colony as a whole. ${ }^{71}$

Given the club-like, rule-bound, 'manifestly exclusive' sociability of the subscription library model, it is unsurprising that women faced restricted access to many colonial institutions in the first half of the nineteenth century. ${ }^{72}$ No women were among the 74 founding subscriber-proprietors of the ASL in 1826, though the library had not seen it necessary to add to the many rules of the institution by prohibiting them. By the time it was decided that 'ladies' could be admitted to the ranks of subscribers by the normal balloting process in 1846, a number of women had already become proprietors by virtue of widowhood or other inheritances. ${ }^{73}$ There was just one woman among the 124 founding subscribers of the TPL in 1849, and none 


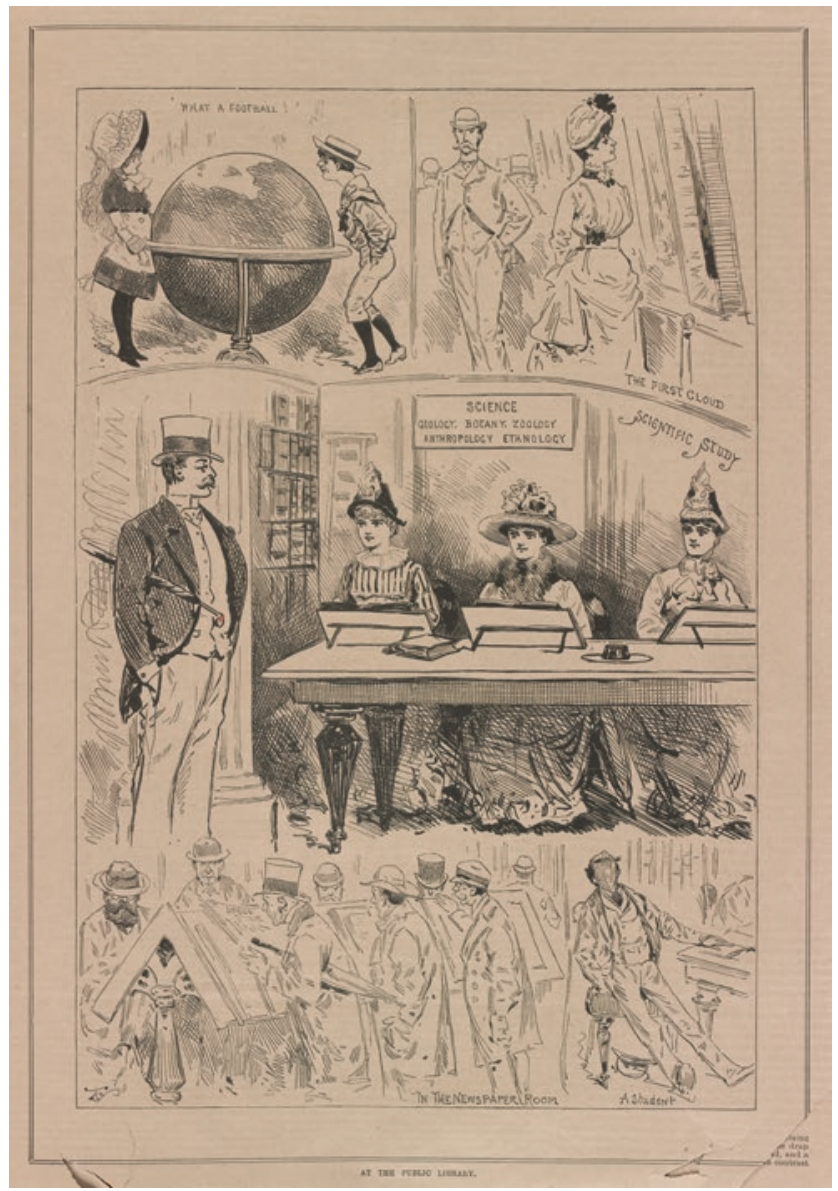

Fig. 3.2 'At the Public Library', wood engraving, Australasian Sketcher, February 23, 1888, Courtesy of the State Library of Victoria: http://handle.slv. vic.gov.au/10381/258786

among the founders of the SL a few years earlier. ${ }^{74}$ By the 1870 s, however, a Miss Little is recorded in the list of proprietors of the SL, the first reference to a female proprietor. ${ }^{75}$ Women were not admitted to the SAPL in its original incarnation, but did come to assert their presence during its phase as a public subscription library. The Attorney General William Porter compared 
the behaviour of 'some ladies' in the SAPL with Miss Lucy Slattern from Sheridan's The Rivals (1775), who 'has the most observing thumb' and 'cherishes her nails for the convenience of making marginal notes' ${ }^{76}$ In 1853, the then Governor of the Cape Colony, Harry Smith, was mildly disturbed that women as well as men were attending the subscribers' meetings, noting that 'while we cordially admit that their "presence civilizes ours" it has nevertheless long been, and will long, I trust, continue to be, the custom of our country, both for their sakes as well as our own, to exclude from what we may term the "public business" of life'. ${ }^{77}$

Despite these difficult beginnings, female participation in public reading culture and literary sociability in the southern colonies was gradually normalised, and eventually, if paternalistically, encouraged. The ALSMI actively sought the attendance of women at their social literary events, and during an 1840 meeting a special appeal was made to women to continue supporting the institute through their presence:

I implore them, as the brightest ornaments of this their adopted land, to aid us further by persuasion-still by example. In such a cause and with such advocates, the barren waste of human ignorance would quickly be transformed to the cultivated garden of knowledge - the forest would resound to the axe-the hunter would advance- the desert would indeed bloom and blossom as the rose. ${ }^{78}$

As with many mechanics' institutes in the Australian colonies, the ALSMI recognised that women could be used as 'marker[s] of respectability' not only for their social events but for the institute's reputation as a whole. ${ }^{79}$ The expectation that women would attend the social events of the institution continued under the SAI as the rules noted that a subscriber's annual 30 -shilling fee 'empowers him to introduce two ladies, or two children, to the lectures or conversaziones of the society'. ${ }^{80}$

The TPL records provide attendance figures for both men and women, and while the number of women users of the library were significantly less than men, the library's six-month reports show a steady increase of women frequenting the library, from 540 in 1860 to 630 in 1861, 637 in 1862, and 659 in $1863 .{ }^{81}$ The MPL marked its liberal principles with the addition of a 'Ladies area' in the new wing of the building opened in $1859 .{ }^{82}$ Female readers, moreover, were not denied any of the access rights enjoyed by men, and by 1874, the Herald praised the 'courageous ladies' who had colonised the library: 


\section{SYNOPSIS OF THE PUBLIC LIBRARY.}

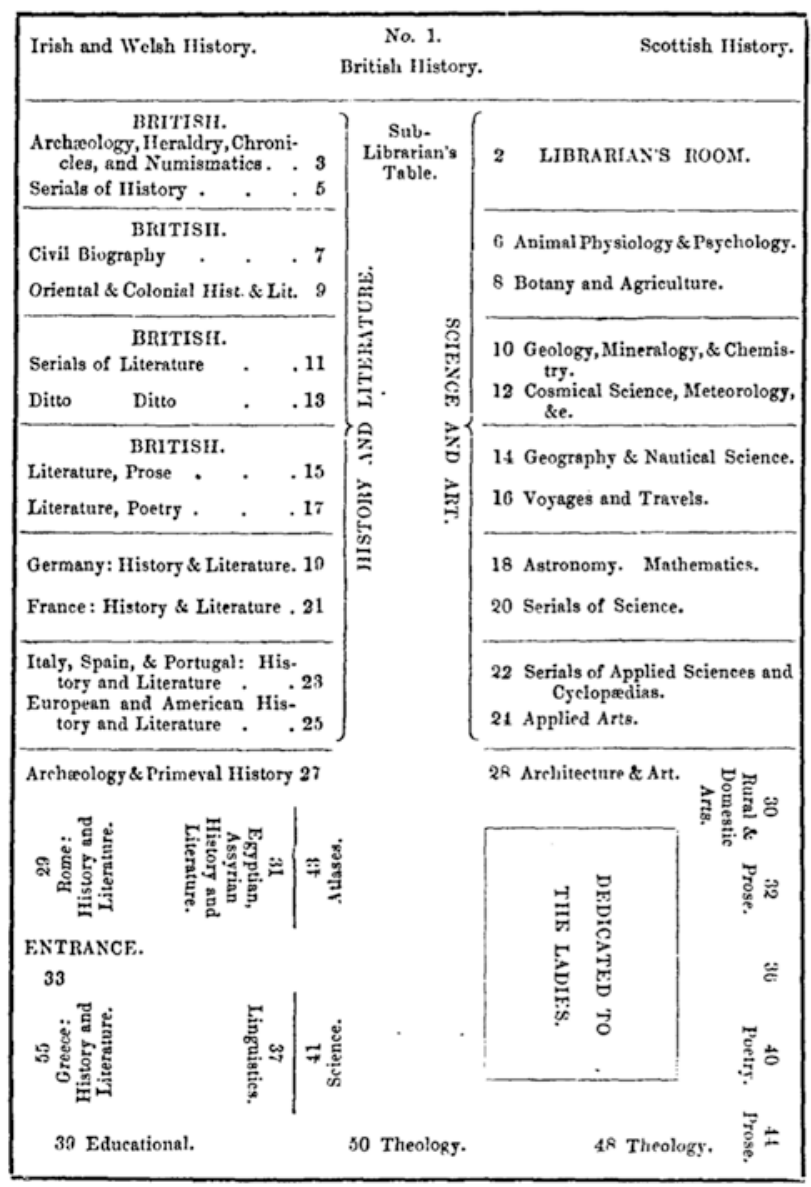

Fig. 3.3 'Synopsis of the Public Library', Catalogue, MPL, 1861, xvi. Courtesy of BCCSH and the State Library of Victoria: http://www.ucd.ie/southhem/ record.html\#112 
helping themselves to books from various quarters in the library, and sitting down to read where they find it most convenient; expressing a tacit dissent from the idea that they should confine themselves to a 'ladies room', furnished with picture books, suitable to their limited understandings.

The Herald even suggested that 'ladies asserting their right to use the library with the same freedom as others' would be the best antidote to loungers and loafers as ' $\mathrm{t}$ ] hey will feel it so extremely awkward indulging in their grunts and snoozes'. ${ }^{83}$ In Singapore, both the SL and RLM were similarly seen as a necessary public amenity for attracting white women to the tropics, who could safeguard against the degeneration of young men. The RLM was therefore 'conceived as a public space suitable for women' ${ }^{84}$

The public library was also viewed as providing 'positive protection' for working-class women, who, because of their colonial setting, were 'without any family connections'. During the debate over Sunday opening hours at the MPL, a letter to the Argus argued in favour of Sunday opening for the 'many hundreds of servants, milliners' assistants, shop women, and other females who have no time at all to read any books during week days' ${ }^{85}$ Similar claims were made in relation to an attempt to decrease the evening opening hours of the FPL in Sydney. ${ }^{86}$ Another letter to the editor claimed that opening on a Sunday would not only save many a man and woman from 'ruin' but would also produce better readers and thus better citizens. Having rested on Saturday night, 'let these minds clear and refreshed, have the Library on Sunday, and very few of them would be satisfied with "picture books"' ${ }^{87}$ While the focus of public libraries in the colonies was undoubtedly on the influence they could exert on young men, such libraries were increasingly viewed as important for members of both genders, and women's presence within their walls not only tolerated but encouraged.

Yet despite the increasing 'assertion' of 'their right to use the library', the presence of women could nonetheless be a distraction for men, and the unwanted attention of men could in turn discourage women from frequenting the library. ${ }^{88}$ Richard Altick and Kate Flint have shown how the 'hordes of loungers' using British public libraries could 'not only put off potential women users ... but did not fit in with their administrators' impression about what formed a suitable environment for the female sex'. ${ }^{89}$ Creating the right public space for women was therefore an important element in determining a public library's success. The lack of a ladies' room in the original MPL building prompted a discussion in the legislative 
council in 1858 and a number of letters from women swiftly appeared in the Argus, pointing to the necessity of a ladies' room to save women from the 'observation [of] many masculine eyes' ${ }^{90}$ One woman wrote that she did not 'possess [the] degree of courage' necessary to 'face the number of eyes which are raised, apparently in astonishment, when a lady makes her appearance in the present reading room, and which follow her every movement'. ${ }^{91}$ Another writer directly confronted the disdainful characterisations of women who dared to 'infiltrate' the public library, arguing that women would require 'a separate room' until men did 'not consider a woman who reads anything more solid than poem or a novel as meddling with things that do not concern her' and as 'blue-stockings'. ${ }^{92}$

The gendering of reading spaces in the public library meant that these spaces themselves became coded by the types of reading associated with women. Examining the 'synopsis of the public library' provided in the 1861 MPL catalogue (Fig. 3.3), one can see that the area 'dedicated to ladies' is surrounded by categories of books such as 'Rural \& Domestic Arts', 'Prose', 'Poetry', and 'Architecture \& Art'. Unsurprisingly, Melbourne Punch played with the association of the ladies' room with frivolous activity and when a ban on eating in the room was enforced, the newspaper mocked the 'dear creatures! to be debarred from eating a bun, and even a bon-bon! ... They may read about the Sandwich Islands, but not partake of a sandwich'. ${ }^{93}$ Despite these jests at the expense of women users of the library, by 1871 the ladies' room appears to have grown significantly and is no longer placed in the 'light reading' section of the MPL. Rather tellingly, one of the walls of the room is now shared with the section dedicated to 'scientific societies transactions'. ${ }^{94}$

\section{Indigenous and Non-British Readers}

Indigenous subjects had very different rights across the British Empire, and their access to and engagement with colonial public libraries and other institutions of knowledge was similarly diverse. In Singapore, the education of the 'native population of the Colony' was a conspicuous part of the rhetoric surrounding the establishment of the RLM. While it was considered important that efforts should be made 'to convince the Native Princes and Rajaks of the policy of sending their sons to participate in the benefits' of the Singapore Institution Free School, the then Governor of the Straits Settlements, Andrew Clarke, proposed in 1874 that the RLM would itself be 'made the means of affording instruction not only to children, but 
to the adult population'.$^{95}$ Noting how different it was for British students, raised from birth with the principles of self-improvement and selfeducation, Robert Little, the future Chairman of the RLM, similarly argued in an address to the Singapore Legislative Council in 1874 that while the government was able to 'educate the native population of the Colony only up to a certain extent', they were nonetheless 'bound to do something to advance their education' after leaving school. Adopting a popular trope in nineteenth-century humanitarian discourse, Little drew comparisons between the Indigenous populations of the Straits and the poor of Britain and Europe when he argued that this 'could only be done by establishing libraries, "those vast armouries open to all indeed, but where the poor may always find their weapons".${ }^{96} \mathrm{He}$ also noted that public libraries would have a positive effect on the crime rate associated with both European pauperism and Chinese and Malay communities, suggesting the extent to which the civilising mission directed at Indigenous populations shared many features with the 'paternalistic' approach to loaferism and other unacceptable forms of 'whiteness' discussed above. ${ }^{97}$

Such arguments were, of course, also heavily bound up with the need to create a so-called comprador class of elite Indigenous and mixed-race civil servants in the colonial world. Little's desire to extend the role of Indigenous clerks from what he called 'mere copyists' to 'originators', who were able both to manage their own learning and to progress within the ranks of the civil service, was ultimately a means of encouraging Britishness. Yet it is significant that the proposed re-invigoration of Stamford Raffles's original vision for 'the cultivation of the languages of China, Siam, and Malay Archipelago, and the improvement of the moral and intellectual condition of the inhabitants of those countries', involved some sense of mutual exchange, not least because the library was, for the first time, to collect manuscripts and ethnographic works relating to the region, and to be united with a museum 'illustrating the products of the Malay Peninsula and Archipelago'. ${ }^{98}$ The fact that at its opening in late 1874 the library had only attracted 102 subscribers out of a general population of over 96,000 people suggests that such lofty goals were hardly realised in practice. ${ }^{99}$ While the 1877 RLM catalogue indicates that there was one Chinese member of the library governing committee and some wealthy Chinese and Malay subscribers, there is no available information on the extent to which 'native' populations visited the free reading room of the RLM. ${ }^{100}$ There is also no detailed information in library reports on the nationalities of subscribers until 1904 , at which point $72 \%$ of subscribers were British and $81 \%$ were 
European (British, Dutch, German, etc.). The other 19\% were predominantly Chinese. Even as late as 1922, the books in the library were mainly in English. ${ }^{101}$

Ambitions to educate the 'native' populations of Singapore, whether realised or not, were conspicuous by their absence in the establishment of public libraries in the South African and Australian colonies. In the Cape Colony, Indigenous literacy - and that of mixed-race bastaard and griqua communities - was primarily addressed by mission schools. Some mission stations such as Bethelsdorp, Genadendal, and Kat River had significant circulating libraries and relatively high English-language literacy levels among their primarily Khoisan communities, ${ }^{102}$ but these stations in the Western and Eastern Cape were generally outside urban centres, and missionaries had little contact with the SAPL and its governing body. The 'Malay' ex-slave and Muslim community of Cape Town was served by its own networks of imams and madrasas. ${ }^{103}$ The Molteno Regulations of 1874 technically allowed Indigenous and other non-white populations access to all reading rooms and reference material, but neither of these two groups was ever addressed either directly or indirectly by the SAPL. Put simply, they fell outside of the boundaries of who the SAPL committee members considered to be colonial citizenry. It was not until 1905 that F. S. Lewis, then Chief Librarian of the SAPL, could note that '[c] oloured people of all nationalities use these rooms, and one Malay is a subscriber' ${ }^{104}$

In the Australian colonies, where Indigenous populations were in the minority by the mid-nineteenth century, there was little thought given to Indigenous literacy and education outside of mission schools and libraries, which were completely separated from the wider community. ${ }^{105}$ Even in Singapore and Penang, where Indigenous and diasporic populations were in the majority, laissez fare attitudes towards the education of Indigenous populations, relatively high subscription fees, and the stocking of predominantly English or other European-language books meant that Indigenous investment in colonial libraries was limited to small groups of wealthy elites and the emerging literate middle classes. Public libraries, like other clubs and places of sociability, also acted as instruments of acculturation that were used to convey notions of Britishness both to British settlers and Indigenous elites. The social role of public libraries as places for lectures, classes, concerts, recitations, conversaziones, dances, and other recreational pursuits enhanced their function as bastions of 'whiteness' and middleclass social respectability. In this sense, public libraries, like other colonial clubs and associations, were the intellectual equivalent of the colonial 
"hill station", a place where colonists could go to rest and recuperate from the rigours of an alien environment'. ${ }^{106}$ Despite their advocacy of free universal access, the cultural and social politics of colonial public libraries therefore contributed to, and even consolidated, the structures of colonial racism or what Stoler has called the 'private and public boundaries of race' well into the twentieth century. ${ }^{107}$

While the English-language emphasis of colonial public libraries corroborates to some extent James Belich's 'Anglo-divergence' model of the Anglophone settler revolution, European non-British readers, such as German and Dutch emigrants, fared somewhat better than Indigenous readers. ${ }^{108}$ The SAI, for example, was prepared and even keen to cater for its German colonists, seeing itself as a 'national institution' for the 'education of the whole nation' rather than simply for the British contingent. ${ }^{109}$ Ordering German titles was therefore a stated policy of the SAI, with committee notes recording the 'arrangements for the immediate importation of the best standard authors of Germany in the original language', supervised by 'resident German gentlemen'. ${ }^{110}$ It was hoped that the German literature would become 'a prominent feature in the library' and 'be the means of increasing the number of German subscribers'. ${ }^{11}$ Despite the high quality of the collection, the number of German titles held at the SAI was small: 53 titles of German literature out of approximately 4054 titles are listed in the SAI's 1861 catalogue. By 1869, 63 titles of German literature are listed out of approximately 6506 titles. ${ }^{112}$ While German colonists had German-language newspapers, such as South Australia's short-lived Deutsche Post (est. 1848), ${ }^{113}$ the SAI nonetheless recognised the importance of adapting their collection to the local needs and conditions of their colony, which was considered to be a defining characteristic of becoming a 'national' institution.

Apart from the partly Dutch-language Dessinian Collection of 4565 volumes, the SAPL also registered some desire to cater for the longestablished Dutch population of the Cape. Of the 1584 titles listed in its 1829 catalogue, there are 157 Dutch titles in all genres, including natural history, voyages and travels, and ancient history. ${ }^{114}$ While the library's Dutch-language holdings do not represent a large proportion of the SAPL's total holdings, they nonetheless amount to a numerically significant collection in comparison to the library's other foreign-language holdings (French, German, Italian, and Spanish), and reflect some effort to include the local Anglophile Cape-Dutch elite in the library. Yet by 1842, the Dutch-language works listed in the SAPL's catalogue amount to only 
148 titles, suggesting that there was no ongoing desire to expand the library's Dutch holdings. On the contrary, by 1862, the number of Dutch titles listed is the reduced figure of $117 .{ }^{115}$ While Jardine had maintained collections in Dutch, as well as collecting and preserving Cape print culture, it appears that his successor, Frederick Maskew, was more concerned with disseminating Anglophone literary and intellectual culture in a climate of increasingly intense Boer unrest and frontier warfare. Similarly, the SL made no attempt to stock books in any language other than English until its reincarnation as the RLM in 1874, despite the fact that Singapore was then a centre for commercial publishing in the Malay-Muslim world. ${ }^{116}$

At the SAPL's annual general meeting in 1855 , a motion by the classicist and educationalist Dr Changuion bemoaned the lack of foreign-language literature in the library: 'all our annual accessions are exclusively in English. Now, sir, we ought to encourage the study of foreign languages and literature, as one of the means of promoting enlarged views'. ${ }^{117}$ While Changuion ties the SAPL's emphasis on English-language books to parochialism or a resistance to the multi-lingual cosmopolitan cultures of continental Europe rather than to geo-political interests, Alistair Pennycook and Gauri Viswanathan, among others, have demonstrated how English-language instruction and education was used as part of a strategy to promote 'Britishness' in African, Asian, Indian, and West Indian colonies. ${ }^{118}$ The book acquisition policies of public libraries in the southern colonies suggest a similarly close association between English-language book provision and geo-political interests, particularly in the Cape Colony and Singapore where there was a real material threat to Anglophone cultural hegemony due to the relatively small number of Anglo settlers as compared to other groups.

For colonies with negligible Dutch, French, and German populations, on the other hand, foreign-language collections were more a sign of cosmopolitanism and learnedness than of specific local needs. Although the majority of the works included in the 1861 MPL catalogue are in English and published in London, there are a variety of foreign-language titles listed, including titles in French, German, Italian, Latin, and Spanish. In 1884, C. W. Holgate reported of the MPL that its 'collection of works relating to the language, literature, and history of Germany' was the 'least well represented in proportion to its importance', but in the 1860s the literature section, in particular, demonstrates the library's wide-ranging selection of prestige texts and authors, with works in Greek, Latin, and modern languages such as French, Italian, German, Hungarian, and Russian. ${ }^{119}$ Similarly, the TPL had a small classical and foreign-language 
collection, with its 1855 catalogue listing 31 French titles, 2 German titles, 19 Greek titles, and 20 Latin titles out of a total number of 2112 titles. ${ }^{120}$ While foreign-language titles do not therefore amount to more than $3 \%$ of the TPL's collection, they nonetheless suggest a desire to encourage a cosmopolitan attitude among the library's users and, increasingly, to encourage the purchase and donation of antiquarian collections.

\section{Notes}

1. Patrick Joyce, 'The Politics of the Liberal Archive', History of the Human Sciences 12, no. 3 (1999): 35-49 (39).

2. Michael Warner, Publics and Counterpublics (New York: Zone Books, 2002), 51,81 .

3. David Wittenberg, 'Going Out in Public: Visibility and Anonymity in Michael Warner's "Publics and Counterpublics", Quarterly Journal of Speech 88, no. 4 (2002): 426-433 (426).

4. Ken Gelder and Rachael Weaver, Colonial Australian Fiction: Character Types, Social Formations and the Colonial Economy (Sydney: Sydney University Press, 2017), 1. Elizabeth Fowler, Literary Character: The Human Figure in Early English Writing (Ithaca NY: Cornell University Press, 2003), 2, quoted in Gelder and Weaver, 1.

5. Proceedings, SAPL, 1853, 6: www.ucd.ie/southhem/record.html\#469.

6. Sydney Morning Herald, March 5, 1869, 3.

7. Times (London), October 16, 1841, 5.

8. Sydney Morning Herald, March 5, 1869, 3.

9. The South Australian Institute: Comprising the Public Library, Art Gallery, and Museums. Addresses Delivered at the Laying of the Foundation (Adelaide: W. K. Thomas \& Co, 1879), 14.

10. Eric Richards, 'An Australian Map of British and Irish Literacy in 1841', Population Studies 53, no. 3 (1999): 345-359 (354, 353).

11. Malcolm Wood, Australia's Secular Foundations (Melbourne: Australian Scholarly Publishing, 2016), 66.

12. Kathleen Fennessy, A People Learning: Colonial Victorians and their Public Museums (Melbourne: Australian Scholarly Press, 2007), 16.

13. Johan Fourie, Robert Ross, and Russel Viljoen, 'Literacy at South African Mission Stations', Journal of Southern African Studies 40 (2014): 781-800.

14. J. E. Nathan, The Census in British Malaya 1921 (London: Waterlow \& Sons, 1922), 322, 332; James Francis Warren, Rickshaw Coolie: A People's History of Singapore, 1880-1940 (Singapore: Singapore University Press, 2003), 45.

15. Ann L. Stoler, 'Rethinking Colonial Categories: European Communities and the Boundaries of Rule', Comparative Studies in Society and History 31, no. 1 (1989): 134-161 (150). 
16. Proceedings, SAPL, 1848, 10, 13: www.ucd.ie/southhem/record.html\#464.

17. Proceedings of the Twenty-Sixth Anniversary Meeting of the Subscribers to the Public Library, Cape Town, Cape of Good Hope, Saturday, the 21st April, 1855 (Cape Town: Saul Solomon \& Co., 1855), 2.

18. Proceedings, SAPL, 1853, 6: www.ucd.ie/southhem/record.html\#469.

19. The Third Report of the Singapore Library, 1847 (Singapore: G. M. Frederick at the Singapore Free Press Office, 1848), 4. For a list of subscribers, see The Eighth Report of the Singapore Library, 1851 (Singapore: Mission Press, 1852), 3.

20. Ray Markey, 'Colonial Forms of Labour Organisation in NineteenthCentury Australia' (Wollongong: Department of Economics Working Paper Series, University of Wollongong, 1997), 1-36, accessed August 2, 2018: http://ro.uow.edu.au/cgi/viewcontent.cgi?article=1261\&contex $\mathrm{t}=$ commwkpapers.

21. Shayne Breen, 'Class', in The Companion to Tasmanian History, ed. Alison Alexander (Hobart: Centre for Tasmanian Historian Studies University of Tasmania, 2006), n. p., accessed August 3, 2018: http://www.utas.edu. au/library/companion_to_tasmanian_history/C/Class.htm.

22. Herald (Melbourne), May 27, 1861, 4.

23. Age (Melbourne), June 6, 1885 and Australasian (Melbourne), March, 1869 , both quoted in David McVilly, "“Something to Blow About"?the State Library of Victoria, 1856-1880', La Trobe Journal 8 (1971): 81-90 (83).

24. Sydney Morning Herald, May 22, 1878, 3.

25. Mount Alexander Mail (Castlemaine, Victoria), May 28, 1860, 3.

26. Herald, January 19, 1875, 2.

27. Melbourne Punch, August 25, 1859, 2; July 14, 1859, 3.

28. Lewis C. Roberts, 'Disciplining and Disinfecting Working-Class Readers in the Victorian Public Library', Victorian Literature and Culture 26, no. 1 (1998): 105-132 (120, 127).

29. Mary Hammond, "The Great Fiction Bore": Free Libraries and the Construction of a Reading Public in England, 1880-1914', Libraries \& Culture 37, no. 2 (Spring 2002): 83-108 (96, 86).

30. Mary Carroll and Sue Reynolds, "There and Back Again": Reimagining the Public Library for the Twenty-First Century', Library Trends 62, no. 3 (2013): 581-595 (592).

31. Melbourne Punch, January 17, 1867, 3.

32. Address on the Opening of The Free Public Library of Ballarat East by Sir Redmond Barry (Ballarat: The Star Office, 1869), 11, 14.

33. Joyce, 'The Politics of the Liberal Archive', 41, 44.

34. Argus (Melbourne), April 10, 1863, 5.

35. The First Report of the Singapore Library, 1844 (Singapore: Mission Press, 1845), 7. 
36. Alistair Black, 'The People's University: Models of Public Library History', in The Cambridge History of Libraries in Britain and Ireland Volume III 1640-1850, ed. Giles Mandelbrote and K. A. Manley (Cambridge: Cambridge University Press, 2006), 24-39 (32); 'The Library as Clinic: A Foucauldian Interpretation of British Public Library Attitudes to Social and Physical Disease, ca. 1850-1950', Libraries \& Culture 40, no. 3 (1995): 416-434 (426).

37. South Australian Weekly Chronicle (Adelaide), September 1, 1866, 4.

38. Black, 'The People's University', 32.

39. Melbourne Punch, May 19, 1864, 2.

40. South Australian Weekly Chronicle, October 31, 1863, 4.

41. Brendan Luyt, 'The Importance of Fiction to the Raffles Library, Singapore, During the Long Nineteenth-Century', Library \& Information History 25, no. 2 (2009): 117-131.

42. Mrinalini Sinha, 'Britishness, Clubbability, and the Colonial Public Sphere: The Genealogy of an Imperial Institution in Colonial India', Journal of British Studies 40, no. 4 (2001): 489-52.

43. Marvin Spevack, 'The Impact of the British Museum Library', in The Cambridge History of Libraries in Britain and Ireland Volume II 16401850, ed. Giles Mandelbrote and K. A. Manley (Cambridge: Cambridge University Press, 2006), 422-437 (427). On this point, see Melbourne Punch, August 2, 1855, 153; and Herald, September 30, 1874, 2. See also Herald, March 28, 1862, 4; December 5, 1876, 2.

44. Hammond, "“The Great Fiction Bore", 84.

45. Melbourne Punch, February 19, 1863, 4.

46. Argus, October 9, 1868, 5.

47. Herald, February 6, 1863, 5 .

48. North Australian (Ipswich, Queensland), December 17, $1863,7$.

49. Age, February 18, 1856, 3.

50. Age, March 24, 1860, 4.

51. David McVilly, 'A History of the State Library of Victoria. 1853-1974' (MA thesis., Monash University, 1975), 38, accessed August 9, 2018: http://handle.slv.vic.gov.au/10381/231567.

52. McVilly, 'A History of the State Library of Victoria', 38.

53. Argus, October 9, 1868, 5.

54. Empire (Sydney), August 5, 1865, 5 .

55. Michael Zakim, 'The Business Clerk as Social Revolutionary; or, a Labor History of the Nonproducing Classes', Journal of the Early Republic 26, no. 4 (Winter 2006): 563-603 (564).

56. Karl Marx, Capital Vol. 1, ed. Frederick Engels, trans. Samuel Moore and Richard Aveling (New York: International Publishers, 1967), 773-774.

57. Age, March 24, 1860, 4. 
58. Argus, October 9, 1868, 5 .

59. Age, March 24, 1860, 4.

60. Herald, January 29, 1863, 4.

61. Melbourne Punch, July 20, 1865, 6.

62. South Australian Weekly Chronicle, October 31, 1863, 4.

63. Cape of Good Hope Literary Gazette, June 29, 1831, 170.

64. Herald, September 7, 1869, 3.

65. Melbourne Punch, January 13, 1887, 3.

66. Herald, September 7, 1869, 3. On diseases in the public library see, for example, Hammond, "“The Great Fiction Bore"”, 89.

67. Black, 'Library as Clinic', 416-434.

68. Harald Fischer-Tiné, 'Britain's Other Civilising Mission: Class Prejudice, European "Loaferism" and the Workhouse-system in Colonial India', The Indian Economic and Social History Review 42, no. 3 (2005): 295-338 $(310,330,298)$.

69. Sydney Morning Herald, March 21, 1844, 2.

70. Proceedings at the Twelfth Anniversary Meeting of Subscribers to the Public Library, Cape Town, Cape of Good Hope, Thursday, 29 April 1841 (Cape Town: s. n., 1841), 5.

71. Melbourne Punch, April 2, 1868, 4.

72. James Raven, 'Libraries for Sociability: The Advance of the Subscription Library', in The Cambridge History of Libraries in Britain and Ireland Volume II 1640-1850, ed. Giles Mandlebrote and K. A. Manley (Cambridge: Cambridge University Press, 2006), 239-263 (250).

73. Catalogue, ASL, 1839: http://www.ucd.ie/southhem/record.html\#30. See also F. M. Bladen, Public Library of New South Wales: Historical Notes, 2nd ed. (Sydney: Govt. Printer, 1911), 27.

74. Heather Gaunt, 'Identity and Nation in the Australian Public Library: The Development of Local and National Collections 1850s-1940s, Using the Tasmanian Public Library as Case Study' (PhD diss., University of Tasmania, 2010), 53, accessed August 6, 2018: https://eprints.utas. edu.au/10772/2/Gaunt_whole.pdf. The First Report of the Singapore Library, 1844 (Singapore: Mission Press, 1845), 2.

75. Straits Times (Singapore), April 24, 1875, 1.

76. Proceedings at the Twenty-Ninth Anniversary Meeting of the Subscribers to the Public Library, Cape Town, Cape of Good Hope, Held on Saturday, The 1st May, 1858 (Cape Town: Saul Solomon, 1858), 14.

77. Proceedings, SAPL, 1853, 6: www.ucd.ie/southhem/record.html\#469.

78. Southern Australian (Adelaide), August 28, 1840, 3.

79. Sarah Comyn, 'Literary Sociability on the Goldfields: The Mechanics' Institute in the Colony of Victoria, 1854-1870', Journal of Victorian Culture 23, no. 4 (2018): 447-462.

80. South Australian Register (Adelaide), May 13, 1856, 2. 
81. Mercury (Hobart), August 21, 1860, 3; July 18, 1861, 2; July 11, 1862, 5; July 10, 1863, 2.

82. Argus, May 25, 1859, 6 .

83. Herald, September 30, 1874, 2.

84. Roland Braddell, The Lights of Singapore (Oxford: Oxford University Press, 1982), 125.

85. Argus, July 13, 1859, 1.

86. Sydney Morning Herald, May 26, 1871, 5.

87. Argus, June 29, 1859, 5.

88. Abigail A. van Slyk, 'The Lady and the Library Loafer: Gender and Public Space in Victorian America', Winterthur Portfolio 31, no. 4 (Winter 1996): 221-242.

89. Kate Flint, The Woman Reader, 1837-1914 (Oxford: Clarendon Press, 1993), 174; Richard Altick, The English Common Reader: A Social History of the Mass Reading Public, 1800-1900 (Chicago: University of Chicago Press, 1957), 238.

90. Age, November 10, 1858, 5; Argus, November 19, 1851, 1.

91. Argus, November 19, 1858, 1 .

92. Argus, November 25, 1858, 7 .

93. Melbourne Punch, November 2, 1865, 3.

94. Report of the Trustees of the Public Library, Museums, and National Gallery of Victoria, with the Reports of the Sectional Committees, for the Year 1870-71 (Melbourne: John Ferres, Government Printer, 1871), accessed August 9, 2018: https://www.parliament.vic.gov.au/vufind/ Record/90063.

95. Straits Times, March 28, 1874, 1.

96. Straits Observer, December 18, 1874, 2; Straits Times, December 26, 1874,4 .

97. Fischer-Tiné, 'Britain's Other Civilising Mission', 298.

98. Straits Times, March 28, 1874, 1.

99. Report on the Raffles Library and Museum for the Year 1875 (Singapore: Government Printing Office, 1876), 1. For the population of Singapore in 1871, see Saw Swee-Hock, 'Population Trends in Singapore, 18191967', Journal of South Asian History 10, no. 1 (1969): 36-49 (39).

100. General Catalogue of Bound Works in the Raffles Library, Sept. 1st 1877, n.p., accessed August 4, 2018: http://eservice.nlb.gov.sg/data2/ BookSG/publish/c/c70105a0-39a8-4ea2-9d99-22dcdb23d62a/web/ html5/index.html?opf=tablet/BOOKSG.xml\&launchlogo=tablet/ BOOKSG_BrandingLogo_.png.

101. Lim Peng Han, 'The Beginning and Development of the Raffles Library in Singapore, 1823-1941: A Nineteenth-Century and Early TwentiethCentury British Colonial Enclave', Library and Information History 25, no. 4 (2009): 265-278 (270). 
102. J. Sales, Mission Stations and the Coloured Communities of the Eastern Cape, 1800-1852 (Cape Town and Rotterdam: A. A. Balkema, 1975), 43.

103. Saarah Jappie, 'Jawi Dari Jauh: 'Malays' in South Africa Through Text', Indonesia and the Malay World 40 (2012): 143-159; Achmat Davids, The Afrikaans of the Cape Muslims from 1805 to 1915, ed. Hein Willems and Suleman E. Dangor (Pretoria: Protean Book House, 2011).

104. F. S. Lewis, 'Memorandum to B. Dyer', April 17, 1905, quoted in Marguerite Andree Peters, 'The Contribution of the (Carnegie) NonEuropean Library Service, Transvaal, to the Development of Library Services for Africans in South Africa' (PhD diss., University of Cape Town, 1974), 23, accessed August 3, 2018: https://open.uct.ac.za/bitstream/handle/11427/14799/thesis_hum_1974_peters_marguerite_ andra_copy_e.pdf?sequence $=1$.

105. See, for example, Ian D. Clark, 'A Peep at the Blacks': A History of Tourism at Coranderrk Aboriginal Station, 1863-1924 (Warsaw and Berlin: De Gruyter, 2015).

106. Luyt, 'The Importance of Fiction', 123.

107. Ann L. Stoler, 'Making Empire Respectable: The Politics of Race and Sexual Morality in twentieth-Century Colonial Cultures', American Ethnologist 16, no. 4 (1989): 634-660 (635).

108. James Belich, Replenishing the Earth: The Settler Revolution and the Rise of the Anglo-World, 1783-1939 (Oxford: Oxford University Press, 2009), 111.

109. South Australian Register, October 18, 1859, 5.

110. Adelaide Times, October 6, 1857, 3; Adelaide Observer, May 1, 1858, 3.

111. South Australian Register, October 18, 1859, 5.

112. Catalogue, SAI, 1861: http://www.ucd.ie/southhem/record.html\#113; Catalogue, SAI, 1869: http://www.ucd.ie/southhem/record.html\#188.

113. H. C. Weibgen, Catalog der Bibliothek/Bendigo Deautscher Verein und Lesehalle (Sandhurst, Vic: C. Jones \& Co, 1874). For German-language libraries in Victoria, see Wallace Kirsop, 'Bendigo's Nineteenth-Century German Library', Bulletin (Bibliographical Society of Australia and New Zealand) 18, no. 2-3 (1994): 169-172.

114. Catalogue, SAPL, 1829: http://www.ucd.ie/southhem/record.html\#264.

115. Catalogue, SAPL, 1842: http://www.ucd.ie/southhem/record.html\#269; Catalogue, SAPL, 1862: http://www.ucd.ie/southhem/record.html\#270.

116. C. M. Turnbull, A History of Modern Singapore, 1819-2005 (Singapore: NUS Press, 2009), 111.

117. Proceedings of the Twenty-Sixth Anniversary Meeting of the Subscribers to the Public Library, Cape Town ... 1855, 12-13.

118. Alistair Pennycook, English and the Discourses of Colonialism (London and New York: Routledge 1998); Gauri Viswanathwan, Masks of Conquest: Literary Study and British Rule in India (New York: Columbia University Press, 1989). 
119. Catalogue, MPL, 1861: http://www.ucd.ie/southhem/record.html\#112. C. W. Holgate, An Account of the Chief Libraries of Australia and Tasmania London: Chiswick, Press, 1886), quoted in Wallace Kirsop, 'German Science in Nineteenth-Century Australian Libraries', The Royal Society of Victoria 127 (2015): 39-42 (39).

120. Catalogue, TPL, 1855: http://www.ucd.ie/southhem/record.html\#312.

Open Access This chapter is licensed under the terms of the Creative Commons Attribution 4.0 International License (http://creativecommons.org/licenses/ by $/ 4.0 /)$, which permits use, sharing, adaptation, distribution and reproduction in any medium or format, as long as you give appropriate credit to the original author(s) and the source, provide a link to the Creative Commons licence and indicate if changes were made.

The images or other third party material in this chapter are included in the chapter's Creative Commons licence, unless indicated otherwise in a credit line to the material. If material is not included in the chapter's Creative Commons licence and your intended use is not permitted by statutory regulation or exceeds the permitted use, you will need to obtain permission directly from the copyright holder.

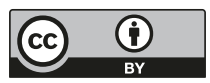

